\title{
KOMPLEMENTER DAN REDUKSI KOMPETISI DALAM KETERKAITAN FUNGSIONAL DUA PUSAT RUANG PERKOTAAN DI KOTA JAYAPURA
}

\author{
Complementary and Reduction of Competition in the Functional \\ Linkages of Two Urban Centers in Jayapura City
}

\section{Alfini Baharuddin ${ }^{1}$, B. Hari Wibisono2 ${ }^{2}$, Budi Prayitno² dan M. Sani Roychansyah²}

\begin{abstract}
Abstrak: Kota Jayapura merupakan ibukota Provinsi Papua yang terletak di ujung timur Indonesia dan mempunyai perbatasan langsung dengan negara tetangga, Papua New Guinea (PNG). Kondisi geografis Kota Jayapura yang sangat beragam mengakibatkan terbentuknya ruang perkotaan yang terpisah-pisah. Saat ini terdapat dua pusat ruang perkotaan di Kota Jayapura yang dikenal dengan sebutan Jayapura dan Abepura. Keadaan ini memunculkan karakter yang unik dalam keseluruhan sistem perkotaan Kota Jayapura, sehingga perlu untuk dikaji bagaimana dua pusat ruang perkotaan tersebut berinteraksi di Kota Jayapura. Penelitian ini bertujuan untuk mengkaji keterkaitan fungsional yang terjadi antara Jayapura dan Abepura dengan menggunakan metode penelitian studi kasus. Pengumpulan data dilakukan melalui observasi langsung, pengumpulan data sekunder dan wawancara terstruktur dengan menggunakan kuesioner. Hasil penelitian menunjukkan bahwa pada keterkaitan fungsional yang terjadi antara Jayapura dan Abepura terdapat fungsi-fungsi yang komplementer dari adanya keunggulan alamiah, dan fungsi-fungsi yang homogen tetapi tidak berkompetisi dalam penyediaan fasilitas ekonomi dan pelayanan publik. Dalam hal ini, fungsi-fungsi homogen yang muncul tidak menyebabkan terjadinya kompetisi, sehingga terjadi reduksi kompetisi.
\end{abstract}

Kata kunci: keterkaitan fungsional, komplementer, reduksi kompetisi, Kota Jayapura

Abstract: Jayapura City is the capital of Papua Province, located at the eastern end of Indonesia and has a direct borders with neighboring countries, Papua New Guinea (PNG). The geographical conditions of Jayapura City are very diverse leads to the formation of separate urban centers. Currently there are two parts of urban centers in Jayapura City, known as Jayapura and Abepura. This situation gave rise to a unique character in the overall system of Jayapura City, so it is necessary to examine how the two urban centers interact in Jayapura City. This study aims to assess the functional linkages that occur between Jayapura and Abepura using the case study method. Data collected through direct observation, secondary data collection and structured interviews using a questionnaire. The results showed that the functional linkages that occurred between Jayapura and Abepura are complementary functions of their natural advantages, and functions that are homogeneous but did not compete in the provision of economic and public service. In this case, the functions homogeneous appearing not cause competition, resulting in a reduction of competition.

Keywords: functional linkages, complementary, reduction of competition, Jayapura City

\footnotetext{
${ }^{1}$ Jurusan Arsitektur Fakultas Teknik Sipil dan Perencanaan, Universitas Sains dan Teknologi Jayapura

${ }^{2}$ Departemen Teknik Arsitektur dan Perencanaan Fakultas Teknik, Universitas Gadjah Mada.
} 


\section{PENDAHULUAN}

Kota Jayapura merupakan ibukota Provinsi Papua yang terletak di ujung timur Negara Republik Indonesia dan mempunyai perbatasan langsung dengan negara tetangga Papua New Guinea (PNG). Luas wilayah Kota Jayapura adalah $940 \mathrm{~km}^{2}$ yang terdiri atas lima distrik/kecamatan, yaitu Distrik Jayapura Utara (5,43\%), Jayapura Selatan $(4,62 \%)$, Abepura (16,56\%), Heram (6,72\%) dan Muara Tami (66,67\%); dan terbagi menjadi 25 kelurahan dan 14 kampung. Dari keseluruhan luas wilayah yang ada, hanya sekitar $43 \%$ luas lahan yang sesuai untuk dikembangkan sebagai kawasan budidaya, sedangkan 57\% merupakan kawasan yang tidak sesuai dikembangkan sebagai kawasan budidaya karena merupakan perbukitan yang terjal, rawa-rawa dan hutan lindung (Bappeda Kota Jayapura, 2014). Saat ini perkembangan kota yang pesat terjadi di empat distrik yaitu Distrik Jayapura Utara, Jayapura Selatan, Abepura dan Heram. Sedangkan Distrik Muara Tami cenderung belum berkembang sebagai area perkotaan dan masih mempunyai kepadatan penduduk yang rendah (19 jiwa $/ \mathrm{km}^{2}$ ) yang dipersiapkan sebagai arah pengembangan Kota Jayapura selanjutnya, yaitu ke arah timur Kota Jayapura hingga perbatasan dengan Negara Papua New Guinea.

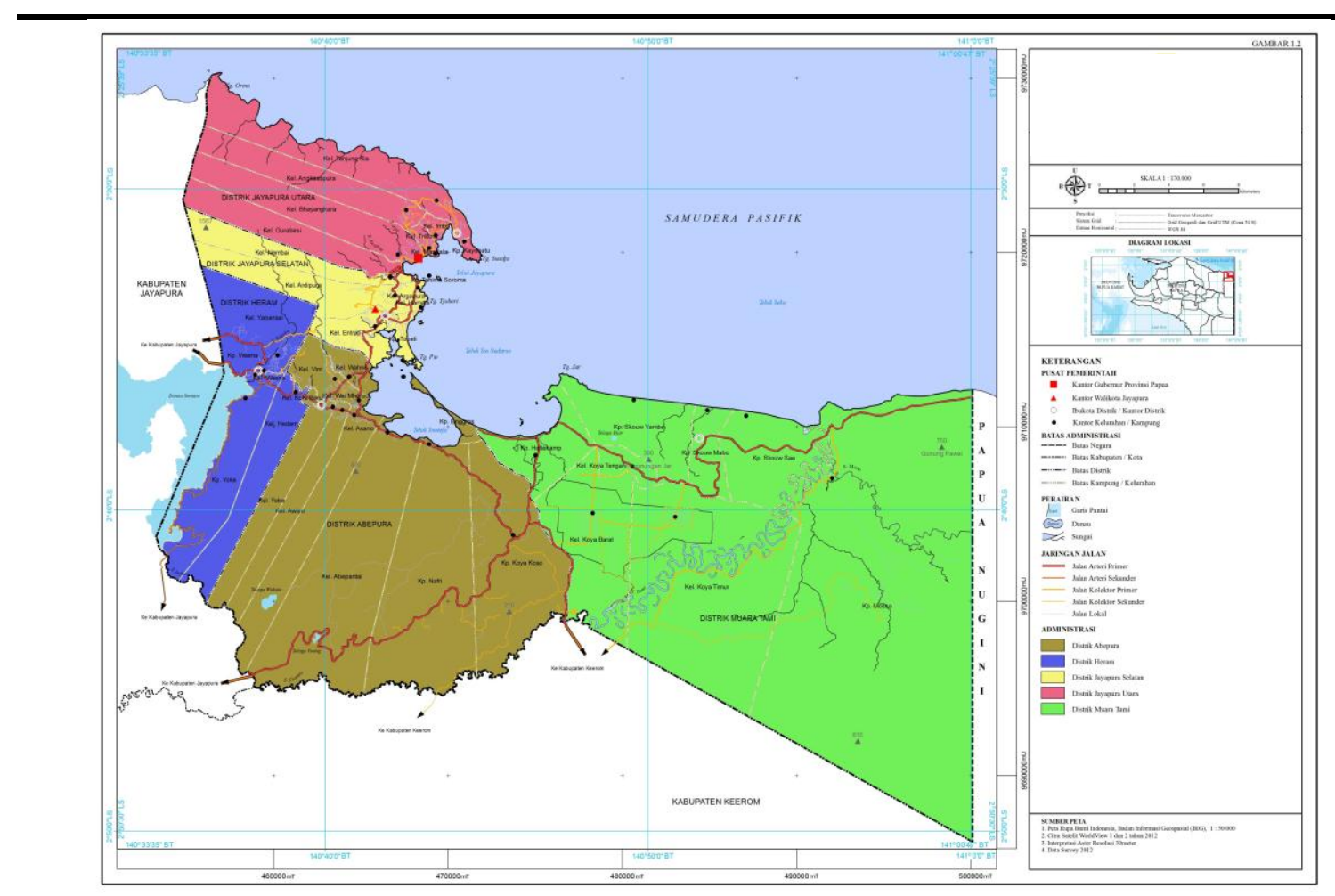

Sumber: Pemerintah Kota Jayapura, 2014

Gambar 1. Peta Wilayah Administratif Kota Jayapura

Kondisi geografis Kota Jayapura yang beragam mengakibatkan terbentuknya wilayh terbangun kota yang terpisah-pisah. Saat ini masyarakat mengenal dua bagian besar wilayah kota di Kota Jayapura, yang dikenal dengan sebutan Jayapura dan Abepura. Wilayah Jayapura mencakup Distrik Jayapura Utara dan Jayapura Selatan, sedangkan wilayah Abepura mencakup Distrik Abepura dan Heram. Kedua wilayah kota ini masing- 
masing mempunyai pusat kota. Pusat kota Jayapura adalah di sekitar Teluk Yos Sudarso, sedangkan pusat kota Abepura berada di sekitar Lingkaran Abepura.

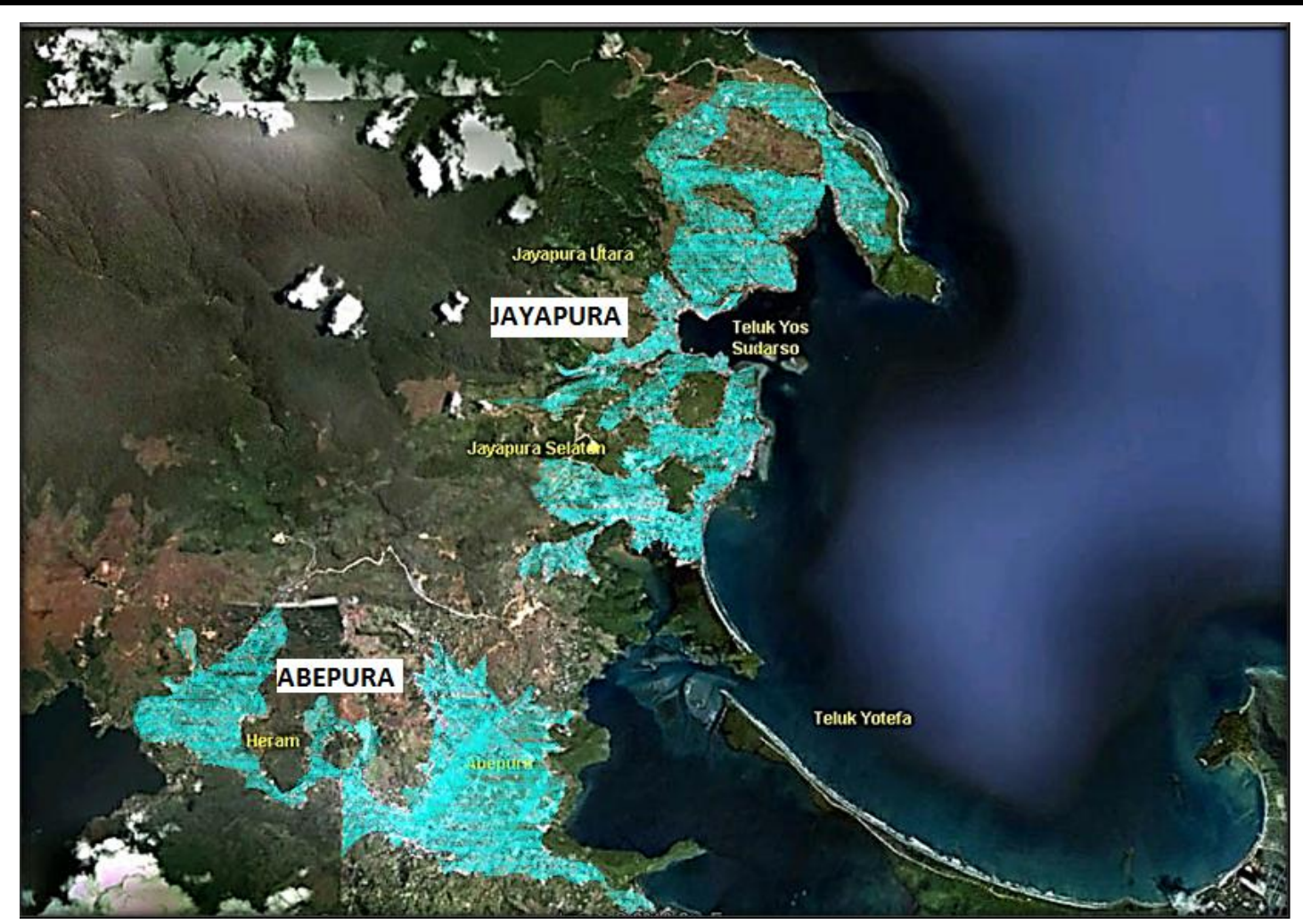

Sumber: Google Earth, 2013, diolah

Gambar 2. Area yang menunjukkan wilayah kekotaan di Kota Jayapura

Wilayah Jayapura dan Abepura dipisahkan oleh perbukitan Skyline dimana jarak antara kedua pusat kota kurang lebih $12 \mathrm{~km}$. Adanya pemisah alami ini semakin mempertegas batas antara kedua wilayah tersebut. Berbeda dengan konsep twin city dimana penggabungan dua kota yang akan berdampak pada peleburan batas-batasnya; atau penggandengan dua kota yang mempunyai kontak dalam zone kontak, maka keadaan geografis Kota Jayapura nampaknya tidak memungkinkan terjadinya peleburan batas-batas dan kontak antara bagian-bagian kota yang terpisah tersebut. Kondisi ini memunculkan karakter yang unik pada keseluruhan sistem keruangan Kota Jayapura yang terbentuk dari keberadaan wilayah Jayapura dan Abepura. Dari kajian literatur, dua kota yang berdekatan akan menghasilkan keterkaitan fungsional yang komplementer dan kerjasama diantara kedua kota tersebut. Namun pada kasus di Kota Jayapura, sebagai dua wilayah kota yang berada dalam satu kesatuan administrasi Kota Jayapura, kecenderungan ini seolah-olah menunjukkan adanya penyediaan pelayanan publik dan ekonomi yang sama (homogen) yang terdapat di Jayapura dan Abepura, sehingga perlu dikaji bagaimana kedua bagian kota tersebut berinteraksi dalam satu kesatuan sistem keruangan Kota Jayapura.

Dua kota yang berdekatan dapat membentuk kota yang dikategorikan sebagai town couple atau double town (Schultz, 2002; Joennimi and Sergunin, 2011). Town couple mengarah pada kompetisi, sedangkan double town mengarah pada kerjasama dan saling melengkapi. Model twin cities lebih mengarah pada double town. Kerjasama yang dihasilkan dari adanya ketidaksamaan (inequality) juga dapat terjadi pada twin cities, 
misalnya sebuah kota yang lebih berfungsi sebagai tempat tinggal dan yang lainnya sebagai pusat bisnis (Buursik, 2001).

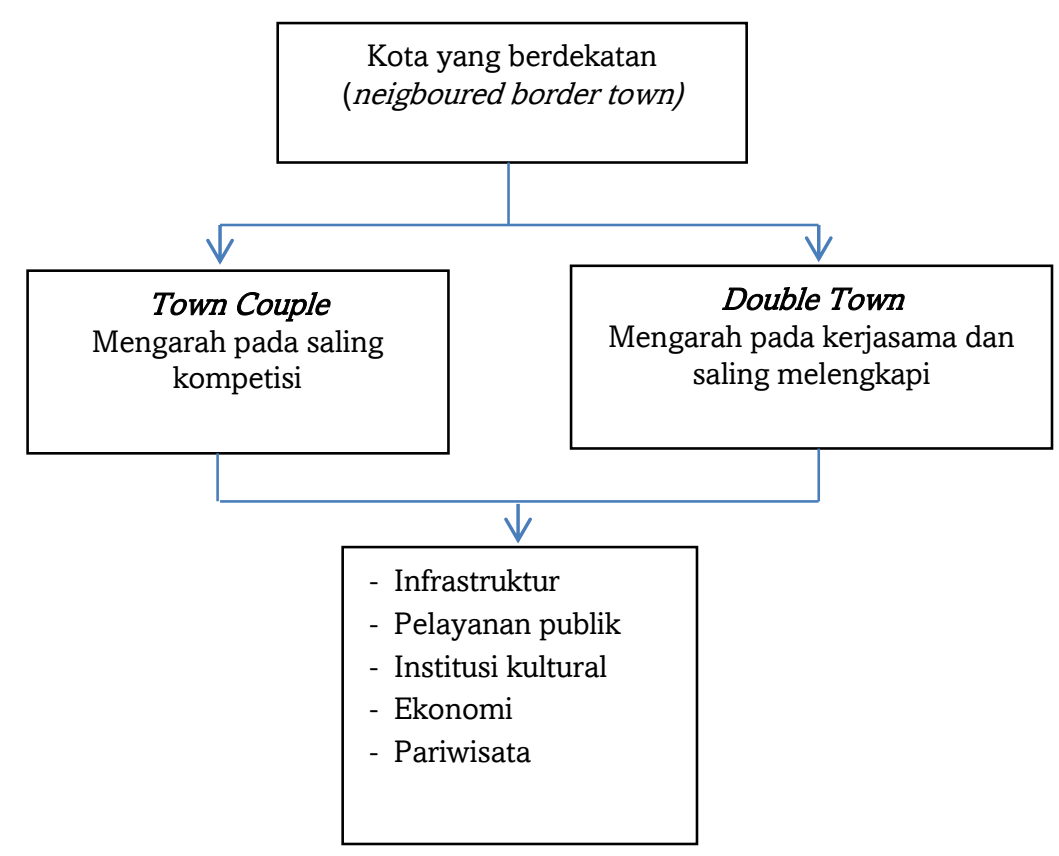

Sumber: Schultz, 2002

Gambar 3. Keterkaitan dua kota yang berdekatan

Salah satu ciri-ciri karakter dari beberapa model jaringan kota adalah adanya hubungan komplementer diantara kota-kota, ciri-ciri lainnya adalah adanya overlapping fungsional dari hinterland dan kotanya sebagai akibat dari integrasi fungsional (Meijers, 2006). Dalam keadaan komplementer, dibutuhkan dua prekondisi yang terkait dengan supply dan demand yaitu harus terdapat diferensiasi dalam supply, dan demand harus paling sedikit sebagian saling tumpang tindih (overlap) (Meijers, 2005). Ciri komplementaritas juga terdapat di Kota Jayapura yang ditandai dengan munculnya beberapa fungsi yang hanya terdapat di wilayah Jayapura yang juga melayani wilayah Abepura, yaitu fungsi pelabuhan, pariwisata (wisata alam) dan perikanan. Munculnya fungsi-fungsi ini disebabkan oleh keunggulan alamiah karena letak wilayah Jayapura yang berada di tepi pantai (teluk), berbeda dengan wilayah Abepura yang berada di daerah hinterland. Disamping fungsi-fungsi komplementer yang muncul karena adanya keunggulan alamiah, muncul pula fungsi-fungsi homogen di Jayapura dan Abepura. Fungsi-fungsi homogen ini mencakup fasilitas pelayanan ekonomi dan jasa diantaranya adalah perdagangan, perbankan, perhotelan, pendidikan, kesehatan, tempat ibadah, kantor pos. Dengan kata lain, beberapa fungsi yang ada di Jayapura juga terdapat di Abepura. Hal ini mengakibatkan munculnya duplikasi dari fungsi-fungsi di kedua wilayah. Secara teoritis, kondisi ini akan mengarah kepada hubungan kompetisi diantara kedua wilayah. Kompetisi merupakan interaksi antara dua kota yang berdekatan yang menjadikan satu sama lainnya sebagai rival (Buursik, 2001). Meijers (2006) mengemukakan bahwa kompetisi interurban lebih mengarah pada duplikasi daripada komplementaritas, dimana 
kompetisi inter-teritorial merupakan serial dari reproduksi, imitasi dan replikasi beberapa ide dari tempat ke tempat. Kota-kota cenderung untuk memasarkan beberapa image yang sama dan meniru bentuk-bentuk yang sama dari perkembangan urban. Hal ini berlawanan dengan komplementaritas yang dianggap bertentangan dengan duplikasi. Duplikasi akan meningkatkan inefisiensi secara ekonomi ketika integrasi fungsional dan aksesibilitas internal di dalam region semakin meningkat.

\section{METODE}

Untuk mengkaji keterkaitan fungsional yang terbentuk antara dua pusat ruang perkotaan di Kota Jayapura yaitu keterkaitan fungsional antara Jayapura dan Abepura, dilakukan pengumpulan data penelitian melalui pengamatan langsung, pengumpulan data sekunder dan wawancara terstruktur dengan menggunakan kuesioner. Langkah pertama pengumpulan data adalah pengumpulan data primer melalui pengamatan langsung berupa data mengenai aktifitas penduduk, aksesibilitas dan transportasi, pergerakan kendaraan dari Jayapura ke Abepura dan sebaliknya, fasilitas pelayanan publik dan fasilitas ekonomi. Pengumpulan data melalui kuesioner ini berupaya menjaring informasi mengenai tempat tinggal, jenis pekerjaan, tempat bekerja, frekuensi melakukan perjalanan ke bagian wilayah kota yang lain (Jayapura atau Abepura), keperluan melakukan perjalanan, dan fasilitas pelayanan publik dan ekonomi yang sering digunakan di bagian wilayah kota yang lain. Pengumpulan data sekunder berupa pengumpulan dokumen tata ruang dan data-data statistik yang terkait dengan penelitian seperti jumlah penduduk, jumlah dan pergerakan kendaraan, jumlah dan sebaran fasilitas kota.

Selanjutnya dilakukan pengumpulan data primer melalui kuesioner terhadap responden yang merupakan penduduk Jayapura dan Abepura. Pengumpulan data dengan menggunakan kuesioner dilakukan untuk menjaring data mengenai pergerakan warga kota dalam pemanfaatan fasilitas. Penentuan responden dilakukan berdasarkan kerangka pemilihan responden yaitu penduduk yang melakukan perjalanan untuk bekerja, berbelanja, memanfaatkan fasilitas pelayanan publik atau bersekolah. Responden merupakan penduduk Jayapura dan Abepura yang dipilih secara acak. Penentuan jumlah responden dilakukan dengan menggunakan Rumus Slovin (dalam Sugiyono, 2011) yaitu:

$$
n=\frac{N}{1+N \cdot 8^{2}}
$$

Dimana: $\mathrm{n}=$ jumlah responden

$$
\begin{aligned}
& \mathrm{N}=\text { populasi } \\
& \mathrm{e}=\text { margin of error, } \mathrm{e}=0,1
\end{aligned}
$$

Rumus ini digunakan karena dalam penelitian ini jumlah populasinya terukur, yaitu jumlah penduduk Jayapura dan Abepura tahun 2013, dimana jumlah penduduk Jayapura adalah 140.277 jiwa dan jumlah penduduk Abepura adalah 130.298 jiwa (BPS Kota Jayapura, 2014). Berdasarkan rumus Slovin, maka diambil jumlah responden Jayapura sebanyak 110 orang dan responden Abepura sebanyak 110 orang.

Penelitian ini menggunakan metode analisis kualitatif dan kuantitatif. Analisis kualitatif dilakukan terhadap data-data yang diperoleh dari pengamatan langsung serta data sekunder. Analisis kuantitatif dilakukan untuk menganalisis data hasil kuesioner yang dianggap mewakili karakteristik dan pergerakan yang dilakukan oleh penduduk Kota Jayapura. Hasil analisis kuantitatif ini digunakan untuk mendukung analisis kualitatif. Data-data dari ketiga sumber data ini selanjutkan dikategorikan dan dikelompokkan 
berdasarkan tema yang sama. Selanjutnya dilakukan analisis untuk menghubungkan data data kualitatif dan data kuantitatif (triangulasi).

\section{HASIL DAN PEMBAHASAN}

\section{Fungsi-fungsi Komplementer \\ Pelabuhan}

Pelabuhan merupakan salah satu infrastruktur yang menunjang peningkatan ekonomi sebuah wilayah terutama dengan adanya aliran arus barang yang keluar masuk dari wilayah tersebut. Kota Jayapura mempunyai sebuah pelabuhan utama yaitu Pelabuhan Jayapura yang berfungsi sebagai pelabuhan penumpang maupun barang. Pelabuhan ini terletak di wilayah Jayapura, di tepi Teluk Yos Sudarso dan berada dekat dengan pusat kota Jayapura. Pelabuhan Jayapura merupakan pelabuhan utama di Provinsi Papua dengan hirarki nasional. Pelabuhan Jayapura mempunyai fungsi yang sangat penting karena selain merupakan pintu masuk ke Kota Jayapura yang melayani arus penumpang dan barang di Kota Jayapura, juga melayani wilayah-wilayah lainnya di sekitar Kota Jayapura, seperti Kabupaten Jayapura dan Kabupaten Keerom. Selain pelabuhan utama, juga terdapat pelabuhan untuk kapal perintis (Pelabuhan Porasko) yang terletak tidak jauh dari pelabuhan utama, namun masih berada dalam lingkup wilayah kerja pelabuhan utama.

Pelabuhan di Kota Jayapura dibangun oleh pemerintah Amerika pada masa Perang Dunia ke-2 sebagai Destroyer Repair Base untuk keperluan perang tentara Amerika. Pada masa pemerintahan Belanda, pelabuhan ini memegang peranan yang sangat penting karena saat itu hampir semua kebutuhan warga kota khususnya orang-orang Belanda yang ada di Hollandia, diimpor dari negeri Belanda. Hingga saat ini pelabuhan Jayapura juga berperan sebagai pemasok berbagai komoditas dari Pulau Jawa dan daerah lainnya di Indonesia, mengingat di Kota Jayapura dan Papua pada umumnya belum terdapat industri yang dapat memenuhi kebutuhan dasar penduduknya.

Dengan adanya pelabuhan di wilayah Jayapura, maka aliran barang yang masuk akan ditumpuk di terminal peti kemas untuk kemudian didistribusikan ke wilayah sekitarnya termasuk ke Abepura. Dengan demikian aliran barang yang terjadi di Kota Jayapura adalah dari wilayah Jayapura ke Abepura. Dalam hal keterkaitan fungsional antara wilayah Jayapura dan Abepura, maka pelabuhan Jayapura merupakan infrastruktur yang dibutuhkan oleh wilayah Abepura untuk keberlangsungan aktifitas di wilayahnya.

\section{Pariwisata}

Beberapa hasil studi menunjukkan pariwisata sebagai salah satu faktor utama dalam hubungan fungsional jaringan kota. Di dalam ESPON (2005) dikemukakan bahwa pariwisata merupakan salah satu fungsi penyeimbang yang kuat di dalam polisentrisitas yang merupakan kekuatan terkuat pendukung polisentrisitas sebagai pembentuk hubungan komplementer antara kota-kota di Eropa yang didorong oleh sektor swasta. Pariwisata juga dapat menghasilkan hubungan kompetisi seperti yang terjadi di Niagara Falls, dimana sebuah obyek wisata terletak di perbatasan dua negara sehingga saling berkompetisi dalam menarik wisatawan (Buursik, 2001).

Letak Jayapura yang berada di tepi Teluk Yos Sudarso menghasilkan banyak potensi wisata alam terutama wisata pantai. Beberapa wisata pantai di wilayah ini antara lain Pantai Base G, Pantai Hamadi, Pantai Pasir II dan Pantai Dok II. Selain itu terdapat pula wisata alam Taman Wisata Teluk Yotefa. Kondisi ini berbeda dengan wilayah Abepura yang tidak banyak mempunyai potensi wisata alam. Hal ini mengakibatkan warga Abepura lebih sering pergi ke wilayah Jayapura untuk berwisata. Dengan demikian, maka 
pariwisata merupakan salah satu faktor yang menghasilkan adanya komplementaritas fungsional wilayah Jayapura dan Abepura.

\section{Perikanan}

Letak wilayah Jayapura yang berada di pesisir pantai menyebabkan sebagian besar penduduk yang bermata pencaharian sebagai nelayan $(89,70 \%)$ bertempat tinggal di wilayah ini. Wilayah Jayapura sebagai penghasil ikan laut juga ditunjang dengan adanya Tempat Pendaratan Ikan (TPI) yang terletak di Hamadi. TPI Hamadi merupakan pemasok ikan laut utama di Kota Jayapura. Hasil perikanan ini kemudian didistribusikan juga ke wilayah Abepura dan wilayah-wilayah lainnya di sekitar Kota Jayapura seperti Kabupaten Jayapura.

\section{Fungsi-fungsi Homogen}

Disamping fungsi-fungsi komplementer yang muncul karena adanya keunggulan alamiah, muncul pula fungsi-fungsi homogen di Jayapura dan Abepura. Fungsi-fungsi yang homogen ini dimaksudkan bahwa kepada fungsi-fungsi yang ada di Jayapura juga terdapat di Abepura, sehingga cenderung mengarah kepada terjadinya duplikasi. Tinjauan terhadap fungsi-fungsi homogen dilakukan terhadap sebaran fasilitas-fasilitas yang menunjang kegiatan perkotaan yaitu perdagangan (pasar dan pusat perbelanjaan), perbankan, perhotelan, pendidikan, kesehatan, peribadatan, kantor pos dan pelayanan kelistrikan (PLTD).

Tabel 1. Jumlah dan Sebaran Fungsi-fungsi Homogen

\begin{tabular}{lcccccc}
\hline Jenis Fasilitas & \multicolumn{2}{c}{ Wilayah Jayapura } & \multicolumn{3}{c}{ Wilayah Abepura } \\
& $\begin{array}{c}\text { Jayapura } \\
\text { Utara }\end{array}$ & $\begin{array}{c}\text { Jayapura } \\
\text { Selatan }\end{array}$ & Jumlah & Abepura & Heram & Jumlah \\
\hline Pasar tradisional & 2 & 1 & 1 & 1 & 3 & 1 \\
Pusat perbelanjaan & 22 & 11 & 33 & 20 & 6 & 26 \\
Perbankan & 20 & 24 & 44 & 9 & 4 & 13 \\
Perhotelan & 64 & 56 & 120 & 72 & 51 & 123 \\
Pendidikan & 51 & 42 & 93 & 78 & 32 & 110 \\
Kesehatan & 123 & 95 & 218 & 105 & 66 & 171 \\
Peribadatan & 2 & 2 & 4 & 2 & 1 & 3 \\
Kantor Pos & & 1 & 1 & & 1 & 1 \\
Pelayanan Kelistrikan (PLTD) & $\mathbf{2 8 4}$ & $\mathbf{2 3 3}$ & $\mathbf{5 1 7}$ & $\mathbf{2 9 0}$ & $\mathbf{1 6 3}$ & $\mathbf{4 5 3}$ \\
Total & & & & & & 5 \\
\hline
\end{tabular}

Sumber: Pengamatan lapangan dan BPS Kota Jayapura, 2014

\section{Indeks Sentralitas}

Adanya fungsi-fungsi yang homogen di wilayah Jayapura dan Abepura dengan jumlah dan sebaran fasilitas yang hampir sama menunjukkan adanya hirarki yang hampir sama pula di kedua wilayah. Jika ditinjau terhadap pengukuran indeks sentralitas dari fungsi-fungsi homogen di kedua wilayah, diperoleh hasil indeks sentralitas Jayapura adalah 1,05 dan indeks sentralitas Abepura adalah 0,94 (Tabel 2). Angka ini menunjukkan bahwa sentralitas Jayapura dan Abepura hampir sama dalam struktur ruang Kota Jayapura. 
Tabel. 2. Indeks Sentralitas Fungsi-fungsi Homogen di Wilayah Jayapura dan Abepura

\begin{tabular}{lllllll}
\hline \multicolumn{1}{c}{ Wilayah } & $\begin{array}{c}\text { Jumlah } \\
\text { Populasi } \\
\text { (jiwa) }\end{array}$ & $\begin{array}{c}\text { \%opulasi } \\
\text { Piwapura }\end{array}$ & $\begin{array}{c}\text { Total Jumlah } \\
\text { Fungsi }\end{array}$ & $\begin{array}{c}\text { Indeks } \\
\text { Fungsi }\end{array}$ & $\begin{array}{c}\text { \% Indeks } \\
\text { Fungsi }\end{array}$ & $\begin{array}{c}\text { Indeks } \\
\text { Sentralitas }\end{array}$ \\
\hline Abepura & 140.277 & 53,81 & 527 & 2,70 & 56,60 & 1,05 \\
Jumlah & 120.398 & 46,19 & 452 & 2,07 & 43,40 & 0,94 \\
\hline
\end{tabular}

Sumber: Hasil Analisis, 2015

Sentralitas dapat meningkat dari adanya fungsi-fungsi yang tidak terdapat di suatu wilayah dan hanya ada di wilayah tertentu (Rondinelli, 1985). Dalam hal ini adalah fungsifungsi yang komplementer. Zhong (2015) mengemukakan bahwa keragaman merupakan komponen kunci dari sentralitas. Jika ditinjau terhadap keragaman fungsi-fungsi di Jayapura dan Abepura yang mencakup fungsi-fungsi komplementer dan fungsi-fungsi homogen, menunjukkan bahwa indeks sentralitas Jayapura adalah 1,12 dan indeks sentralitas Abepura adalah 0,86 (Tabel 3). Angka ini menunjukkan bahwa sentralitas Jayapura lebih besar daripada sentralitas Abepura yang disebabkan karena Jayapura memiliki fungsi-fungsi komplementer yang juga melayani wilayah Abepura.

Tabel 3. Indeks Sentralitas Fungsi-fungsi Komplementer dan Homogen di Wilayah Jayapura dan Abepura

\begin{tabular}{lllllll}
\hline Wilayah & $\begin{array}{l}\text { Jumlah } \\
\text { Populasi } \\
\text { (jiwa) }\end{array}$ & \% Populasi & $\begin{array}{l}\text { Total Jumlah } \\
\text { Fungsi }\end{array}$ & $\begin{array}{l}\text { Indeks } \\
\text { Fungsi }\end{array}$ & $\begin{array}{l}\text { \% Indeks } \\
\text { Fungsi }\end{array}$ & $\begin{array}{l}\text { Indeks } \\
\text { Sentralitas }\end{array}$ \\
\hline Jayapura & 140.277 & 53,81 & 536 & 3,17 & 60,11 & 1,12 \\
Abepura & 120.398 & 46,19 & 454 & 2,11 & 39,89 & 0,86 \\
Jumlah & $\mathbf{2 6 0 . 6 7 5}$ & $\mathbf{1 0 0}$ & & 4,77 & 100 & \\
\hline
\end{tabular}

Sumber: Hasil Analisis, 2015

\section{Pola Pergerakan Penduduk dalam Pemanfaatan Fasilitas}

Hasil kuesioner terhadap responden Jayapura dan Abepura menunjukkan bahwa dalam hal pemanfaatan fasilitas, sebagian besar penduduk Jayapura maupun Abepura memanfaatkan fasilitas ekonomi dan publik yang ada di wilayahnya untuk memenuhi kebutuhan sehari-sehari dan tidak melakukan perjalanan ke wilayah lainnya untuk memenuhi kebutuhan mereka (Tabel 4). Dari 110 responden Jayapura, yang memanfaatkan fasilitas yang ada di Jayapura untuk berbelanja sebanyak 90\%, untuk berobat sebanyak 90\% dan untuk beribadah sebanyak 84,5\%. Dari 110 responden Abepura, yang memanfaatkan fasilitas yang ada di Abepura untuk berbelanja sebanyak $89,1 \%$, untuk berobat sebanyak $90,1 \%$, dan untuk beribadah sebanyak $86,4 \%$. Responden yang memanfaatkan fasilitas di wilayah lainnya, misalnya untuk berbelanja, disebabkan karena tempat kerja mereka berada di wilayah tersebut dan berdekatan dengan pusat perbelanjaan sehingga untuk menghemat waktu mereka sekaligus berbelanja ketika pulang bekerja.

Tabel 4. Pemanfaatan Fasilitas Ekonomi dan Publik oleh Responden di Wilayahnya Sendiri

\begin{tabular}{lll}
\hline Jenis Fasilitas & Responden Jayapura & Responden Abepura \\
\hline Fasilitas belanja & $90 \%$ & $89,1 \%$ \\
Fasilitas kesehatan & $90 \%$ & $90,1 \%$ \\
Fasilitas peribadatan & $84,5 \%$ & $86,4 \%$ \\
\hline
\end{tabular}

Sumber: hasil survei, 2014 
Kang et.al (2012) mengemukakan korelasi antara mobilitas penduduk dan morfologi urban, bahwa ukuran dan bentuk kota merupakan dua faktor penting yang mempengaruhi pola mobilitas intra-urban penduduk kota. Dalam penelitian yang dilakukan pada beberapa area perkotaan di Cina bagian timur laut, diketahui bahwa di satu sisi, mayoritas penduduk mengadakan pergerakan di dalam wilayah yang kecil, yang independen dari ukuran perkotaan yang sebenarnya. Di sisi lain, lebih banyak penduduk yang tinggal di kota-kota dengan ukuran yang lebih besar atau kota-kota dengan bentuk yang lebih tidak teratur cenderung untuk bepergian dalam jarak yang jauh. Hasil penelitian tersebut menunjukkan bahwa ukuran kota yang besar berdampak pada perjalanan jarak jauh oleh sebagian besar penduduk. Bentuk kota yang tidak teratur membatasi pergerakan lokal penduduk tetapi mengarah pada perjalanan jarak jauh. Jika dua kota mempunyai ukuran yang sama, maka lebih sedikit penduduk di kota yang lebih kompak akan membuat perjalanan jarak jauh dibandingkan dengan kota yang kurang kompak. Dalam kota yang kurang kompak (irregular) maka infrastruktur dan sumber daya akan tersebar secara geografis, sehingga individu harus mengadakan lebih banyak pergerakan untuk memenuhi kebutuhannya. Terkait dengan konsep pergerakan, Zipth (dalam Harshorne,1992) menyatakan bahwa terdapat prinsip tunggal untuk menyatakan intensitas dan panjang pergerakan. Zipth menyebut kaidah ini sebagai principle of least effort. Dalam konteks transportasi dan komunikasi, kaidah ini menyatakan bahwa seseorang meminimalkan jarak, memilih jalur yang terpendek, dan memilih lokasi yang terdekat untuk memperoleh barang dan jasa.

Dalam kasus di Kota Jayapura menunjukkan kecenderungan pergerakan penduduk yang terjadi lebih mengarah kepada pergerakan di dalam wilayah yang lebih kecil dan tidak melakukan perjalanan yang panjang untuk memenuhi kebutuhannya. Dalam hal ini penduduk Jayapura akan melakukan pergerakan di dalam wilayah Jayapura untuk memenuhi kebutuhannya, demikian pula dengan penduduk Abepura. Hasil ini sejalan pula dengan studi yang dilakukan oleh Paruntung (2004) di Kota Jayapura yang menunjukkan kecenderungan penghuni perumahan memilih tempat tinggal dengan mempertimbangkan lokasi perumahan yang mudah aksesnya dengan lokasi aktifitas keseharian mereka, yaitu dekat dengan tempat kerja, dekat dengan fasilitas pendidikan, dan dekat dengan fasilitas kesehatan.

Pergerakan penduduk yang terjadi di dalam kluster-kluster wilayah kota yang lebih kecil disebabkan karena telah tersedianya sumberdaya di dalam wilayah tersebut. Dalam hal ini bentuk keseluruhan Kota Jayapura yang irregular tidak mempengaruhi pola pergerakan penduduk untuk melakukan perjalanan yang jauh. Fenomena ini menunjukkan bahwa kondisi morfologis Kota Jayapura yang mengakibatkan terbentuknya kluster-kluster wilayah Kota Jayapura menyebabkan masing-masing wilayah akan mengatur dirinya sendiri untuk menyediakan sumber daya bagi penghuninya. Sehingga kondisi morfologis membentuk kemandirian masing-masing wilayah kota di dalam Kota Jayapura, yang berpengaruh pada pola pergerakan penduduk.

Jika ditinjau terhadap data pergerakan kendaraan dari Jayapura ke Abepura dan sebaliknya, menunjukkan bahwa jumlah volume kendaraan penumpang (orang) yang melintasi jalur utama dari Jayapura ke Abepura maupun sebaliknya dari jam 06.00 sampai 18.00 WIT yang diukur dalam sembilan hari, jumlah kendaraan penumpang yang dari Jayapura menuju Abepura adalah rata-rata sebanyak 12.104 kendaraan roda dua dan 5.316 kendaraan roda empat. Sedangkan untuk kendaraan penumpang dari arah Abepura menuju Jayapura pada waktu yang sama, rata-rata jumlah kendaraan yang melintas adalah 11.650 kendaraan roda dua dan 5.566 kendaraan roda empat (Sugiyarto, 2014). Angka tersebut jika dibandingkan terhadap keseluruhan jumlah kendaraan bermotor roda dua dan roda empat yang ada di Kota Jayapura, yaitu kendaraan roda empat sebanyak 22.407 unit dan kendaraan roda dua sebanyak 134.000 unit (Samsat Kota Jayapura, 2014), maka ratarata prosentase jumlah kendaraan yang melintas dari Jayapura ke Abepura adalah 
kendaraan roda dua sebesar $9,03 \%$ dan kendaraan roda empat sebesar $23,72 \%$. Sedangkan prosentase kendaraan yang bergerak dari Abepura ke Jayapura adalah kendaraan roda dua sebesar 8,69\% dan kendaraan roda empat sebesar 24,84\%. Kondisi ini menunjukkan bahwa jika ditinjau dari jumlah kendaraan yang bergerak ke Jayapura maupun Abepura ndalam waktu yang bersamaan, maka dari kedua arah menunjukkan jumlah yang hampir sama. Hal ini menunjukkan bahwa kekuatan daya tarik dari Abepura menuju Jayapura maupun sebaliknya cenderung sama, dalam arti daya tarik Jayapura dan Abepura cenderung seimbang.

\section{Pergerakan Barang}

Sebagaimana dengan pergerakan orang, data mengenai pergerakan barang yang ditunjukkan oleh jumlah kendaraan barang yang melintas dari Jayapura ke Abepura dan sebaliknya dalam waktu yang sama menunjukkan jumlah yang hampir sama besar, yaitu jumlah kendaraan barang yang bergerak dari Jayapura ke Abepura adalah 12,66 \% dari jumlah seluruh kendaraan barang yang ada di Kota Jayapura, sedangkan kendaraan barang yang bergerak dari Abepura ke Jayapura adalah 14,11 \% dari jumlah seluruh kendaraan barang yang ada di Kota Jayapura.

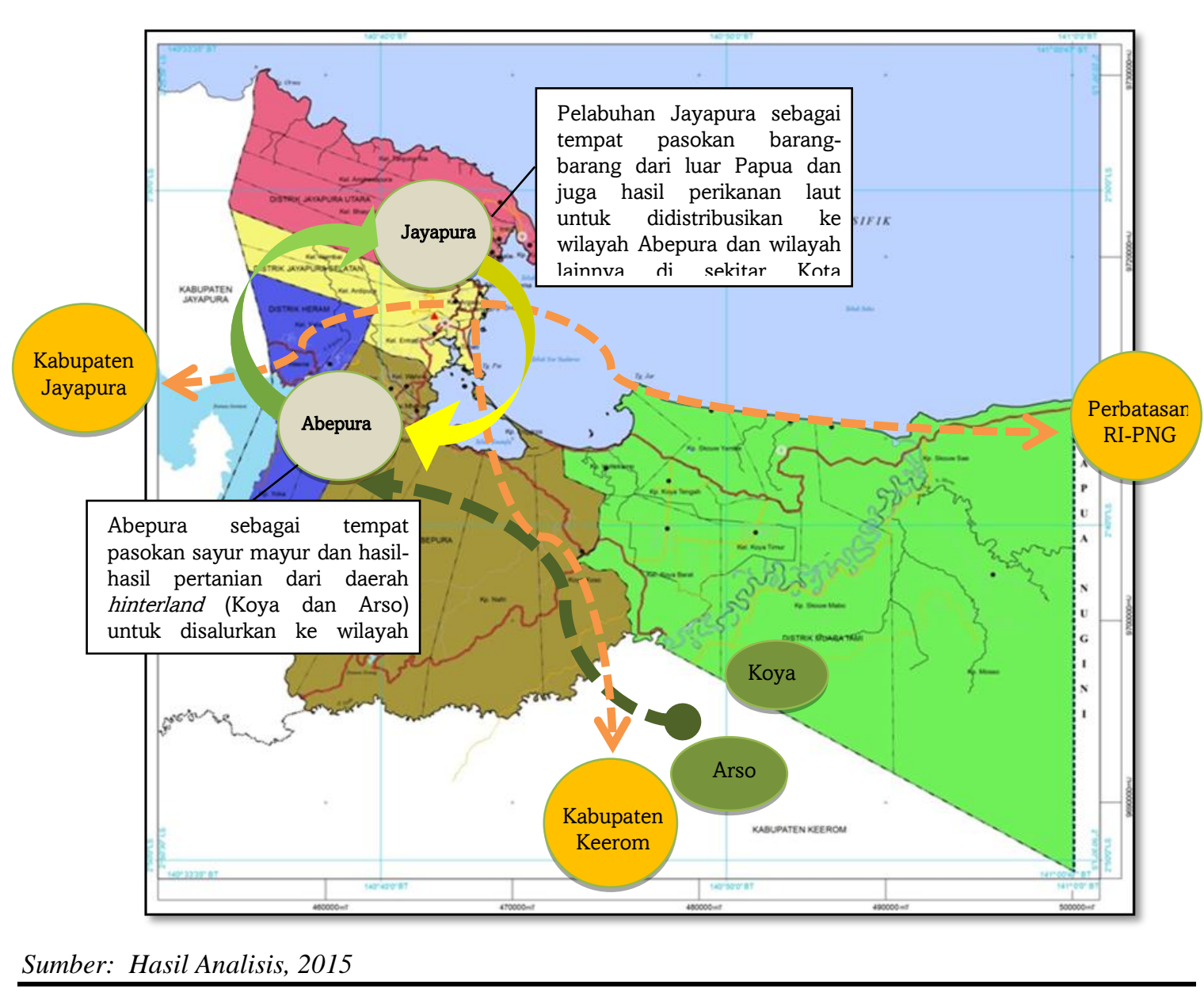

Gambar 4. Hubungan Komplementer dalam Pergerakan Barang di Kota Jayapura 
Pola distribusi barang di Kota Jayapura menunjukkan hubungan yang saling komplementer di kedua wilayah (Gambar 4). Jayapura yang mempunyai pelabuhan laut memegang peranan penting sebagai pintu masuk bagi barang-barang kebutuhan masyarakat dari luar Jayapura. Dari pelabuhan laut ini kemudian barang-barang tersebut didistribusikan ke wilayah Abepura dan wilayah-wilayah lainnya di sekitar Kota Jayapura. Sedangkan Abepura yang berperan sebagai pusat pertumbuhan bagi daerah hinterland di sekitar Kota Jayapura, memegang peranan dalam distribusi pasokan hasil-hasil pertanian dari daerah hinterland ke Kota Jayapura. Kebutuhan sayur mayur di Kota Jayapura disuplai dari Koya dan Arso. Sayur mayur tersebut ditampung di Pasar Yotefa Abepura sebelum didistribusikan ke Pasar Sentral Hamadi, maupun oleh pedagang keliling.

\section{Keterkaitan Fungsional Wilayah Jayapura dan Abepura Komplementer}

Salah satu ciri-ciri karakter dari beberapa model jaringan kota adalah adanya hubungan komplementer diantara kota-kota, ciri-ciri lainnya adalah adanya overlapping fungsional dari hinterland dan kotanya sebagai akibat dari integrasi fungsional (Meijers, 2006). Dalam keadaan komplementer, dibutuhkan dua prekondisi yang terkait dengan supply dan demand yaitu harus terdapat diferensiasi dalam supply, dan demand harus paling sedikit sebagian saling tumpang tindih (overlap) (Meijers, 2005). Ciri komplementaritas juga terdapat di Kota Jayapura yang ditandai dengan munculnya beberapa fungsi yang hanya terdapat di wilayah Jayapura yang juga melayani wilayah Abepura, yaitu fungsi pelabuhan, pariwisata (wisata alam) dan perikanan. Munculnya fungsi-fungsi ini disebabkan oleh keunggulan alamiah karena letak wilayah Jayapura yang berada di tepi pantai (teluk), berbeda dengan wilayah Abepura yang berada di daerah hinterland. Hubungan komplementer juga terjadi dalam pergerakan barang antara Jayapura dan Abepura.

\section{Homogen tetapi tidak berkompetisi (reduksi kompetisi)}

Disamping fungsi-fungsi komplementer yang muncul karena adanya keunggulan alamiah, muncul pula fungsi-fungsi homogen di Jayapura dan Abepura. Fungsi-fungsi homogen ini mencakup fasilitas pelayanan ekonomi dan jasa, diantaranya adalah perdagangan, perbankan, perhotelan, pendidikan, kesehatan, tempat ibadah, kantor pos. Dengan kata lain, beberapa fungsi yang ada di Jayapura juga terdapat di Abepura. Hal ini mengakibatkan munculnya duplikasi dari fungsi-fungsi di kedua wilayah. Secara teoritis, kondisi ini akan mengarah kepada hubungan kompetisi diantara kedua wilayah. Kompetisi merupakan interaksi antara dua kota yang berdekatan yang menjadikan satu sama lainnya sebagai rival (Buursik, 2001). Meijers (2006) mengemukakan bahwa kompetisi interurban lebih mengarah pada duplikasi daripada komplementaritas, dimana kompetisi interteritorial merupakan serial dari reproduksi, imitasi dan replikasi beberapa ide dari tempat ke tempat. Kota-kota cenderung untuk memasarkan beberapa image yang sama dan meniru bentuk-bentuk yang sama dari perkembangan urban. Hal ini berlawanan dengan komplementaritas yang dianggap bertentangan dengan duplikasi. Duplikasi akan meningkatkan inefisiensi secara ekonomi ketika integrasi fungsional dan aksesibilitas internal di dalam region semakin meningkat.

Duplikasi ditunjukkan dari adanya fungsi-fungsi ekonomi dan publik yang cenderung homogen di Jayapura dan Abepura. Namun dari analisis pergerakan penduduk menunjukkan bahwa pergerakan penduduk Jayapura dan Abepura cenderung terjadi di dalam wilayahnya masing-masing. Penduduk Jayapura cenderung beraktifitas dan memanfaatkan fasilitas di dalam wilayah Jayapura, tidak memanfaatkan fasilitas di wilayah lainnya. Demikian pula dengan penduduk Abepura. Hal ini disebabkan karena 
fasilitas yang diperlukan oleh penduduk telah tersedia di wilayahnya masing-masing sehingga mereka tidak perlu melakukan perjalanan ke wilayah lainnya untuk memenuhi kebutuhannya. Kondisi ini menggambarkan bahwa tidak terjadi persaingan diantara kedua wilayah walaupun terjadi kecenderungan adanya duplikasi fungsi-fungsi di kedua wilayah. Dengan kata lain, terjadi homogenitas fungsi tetapi tidak berkompetisi. Masing-masing wilayah menyediakan sumberdaya (fungsi) untuk masing-masing populasinya. Hal ini mengakibatkan terjadinya reduksi kompetisi dari adanya duplikasi fungsi-fungsi homogen.

Jika dibandingkan antara fungsi-fungsi homogen dengan komplementer, maka lebih sedikit fungsi-fungsi komplementer yang dikembangkan di Jayapura dan Abepura untuk melayani kedua kota, dimana fungsi-fungsi yang homogen lebih dominan daripada fungsifungsi yang komplementer. Keadaan ini mengakibatkan kurangnya diferensiasi dan integrasi kedua kota. Hal ini ditunjukkan dari pengukuran indeks sentralitas terhadap fungsi-fungsi homogen yang menunjukkan angka yang hampir seimbang, yaitu indeks sentralitas Jayapura 1,05 dan Abepura 0, 94. Angka ini juga tidak berbeda jauh jika indeks sentralitas diperhitungkan juga terhadap fungsi-fungsi komplementer, menjadi Jayapura 1,12 dan Abepura 0,86. Dalam pengukuran ini, indeks sentralitas Jayapura menjadi lebih besar karena fungsi-fungsi komplementer berada di Jayapura yang disebabkan karena keunggulan wilayah Jayapura yang terletak di teluk.

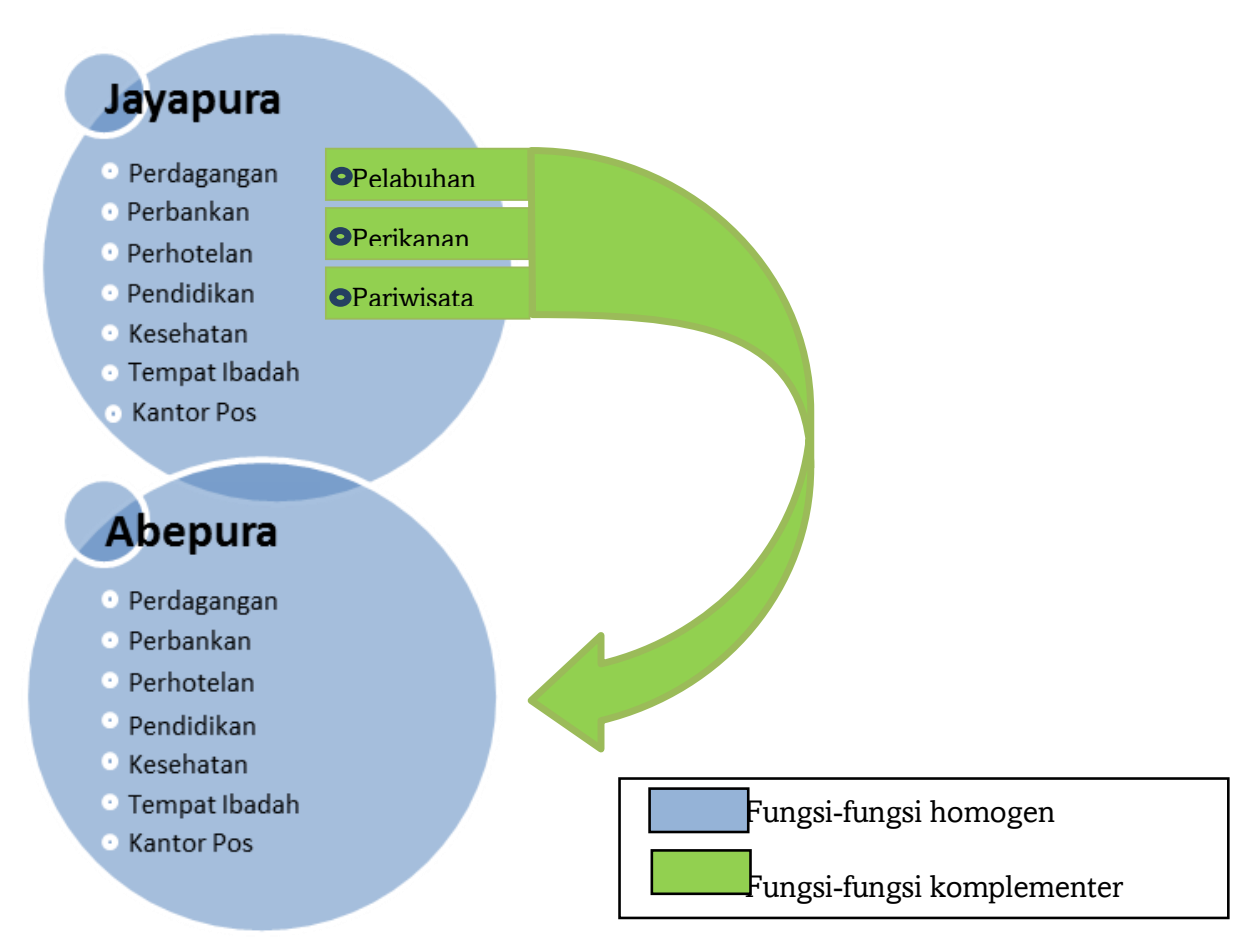

Sumber: hasil analisis, 2015

Gambar 5. Diagram pola fungsional Kota Jayapura

\section{KESIMPULAN}

Dari hasil pembahasan terhadap keterkaitan fungsional, menunjukkan bahwa di Jayapura dan Abepura terjadi kecenderungan munculnya fungsi-fungsi yang komplementer dan fungsi-fungsi yang homogen. Munculnya fungsi-fungsi yang komplementer ini disebabkan karena adanya keunggulan alamiah yang dimiliki oleh sebuah ruang perkotaan yang tidak terdapat di ruang perkotaan lainnya. Fungsi-fungsi komplementer ini terdapat 
di wilayah Jayapura yang berupa pelabuhan, perikanan dan pariwisata (wisata alam). Sedangkan fungsi-fungsi yang homogen muncul dalam hal penyediaan fasilitas ekonomi dan pelayanan publik yang terdapat di kedua wilayah, Jayapura dan Abepura. Secara teoritis, munculnya fungsi-fungsi yang homogen (duplikasi) akan menghasilkan kompetisi di dalam sebuah kota. Namun dalam hal pemanfaatan fasilitas, masing-masing penduduk ruang perkotaan cenderung memanfaatkan fasilitas yang ada di ruang kotanya saja, tidak memanfaatkan fasilitas di ruang perkotaan yang lain. Hal ini mengakibatkan tidak terjadinya kompetisi antara ruang perkotaan Jayapura dan Abepura. Dalam hal ini, fungsifungsi homogen yang muncul tidak menyebabkan terjadinya kompetisi, sehingga terjadi reduksi kompetisi. Dengan demikian terbentuk keterkaitan fungsional berupa komplementer dan reduksi kompetisi antara dua ruang perkotaan yang terdapat di Kota Jayapura.

\section{DAFTAR PUSTAKA}

BPS Kota Jayapura. (2014). Kota Jayapura dalam Angka.

Bappeda Kota Jayapura. (2014). Rencana Tata Ruang Wilayah Tahun 2013-2033.

Buursink, J. (2001). The Binational Reality of Border-Crossing Cities. GeoJournal, Vol. 54, No. 1, pp. 7-19.

ESPON 1.1.1. (2005). Potentials for polycentric development in Europe. SWEDEN: Nordregio.

Hartshorn, T. A. (1992). Interpreting The City: An Urban Geography. Toronto: John Wiley \& Sons.

Joenniemi, P., \& Sergunin, A. (2011). When Two Aspire to Become One: City-Twinning in Northern Europe. Journal of Borderlands Studies, 26:2, 231-242.

Kang, C., Mab, X., Tongc, D., \& Liu, Y. (2012). Intra-urban human mobility patterns: An urban morphology perspective. Physica A, 391, 1702-1717.

Meijers, E. (2005). Polycentric Urban Regions and the Quest for Synergy: Is a Network of Cities More than the Sum of the Parts? Urban Studies, Vol.42 No.4, 765-781.

Meijers, E. (2006). The notion of complementarity in urban networks: definition, value, measurement and development. Response paper presented at the10th UNECE Conference on Urban and Regional Research. Bratislava.

Paruntung M. (2004). Faktor-faktor yang Mempengaruhi Pemilihan Lokasi Perumahan Perumnas IV Padangbulan Kota Jayapura. Tesis tidak dipublikasikan. Program Magister Perencanaan Pembangunan Wilayah dan Kota, Universitas Diponegoro.

Rondinelli, D. A. (1991). Asian Urban Development Policies in the 1990s: From Growth Control to Urban Diffusion. World Development, Vol.19 No.7, pp.791-803.

Schultz, H. (2002). Twin Towns on the Border as Laboratories of European Integration. Frankfurt: Frankfurter Institut für Transformationsstudien.

Sugianto, A. (2014). Evaluasi Kinerja Simpang Tiga Tak Bersinyal (Studi Kasus Daerah Skyine, Simpang Vihara), Skripsi tidak dipublikasikan, Jurusan Teknik Sipil FTSP, Universitas Sains dan Teknologi Jayapura.

Sugiyono. (2011). Metode Penelitian Kuantitatif, Kualitatif, dan R\&D. Bandung: Alfabeta.

Zhong, C., Schlapfer, M., \& Arisona, S. M. (2015). Revealing Centrality in The Spatial Structure of Cities From Human Activity Patterns. Urban Studies, 1-19. 